\title{
Sound velocity of carbonate melts under high pressure and temperature conditions and the origin of mid-lithosphere discontinuity
}

\author{
Kenji Mibe ${ }^{1}$ and Yoshio Kono ${ }^{2}$ \\ ${ }^{\prime}$ Earthquake Research Institute, University of Tokyo,Tokyo, Japan, mibe@eri.u-tokyo.ac.jp \\ ${ }^{2}$ HPCAT, Geophysical Laboratory, Carnegie Institution of Washington, Argonne, Illinois, USA, ykono@ciw.edu
}

\section{Introduction}

$\mathrm{CO}_{2}$-rich magmas, such as kimberlites and carbonatites, have been reported from all of the Earth's continents including Antarctica. Because both kimberlites and carbonatites are considered to be originated from upper mantle, it is, therefore, reasonable to assume that $\mathrm{CO}_{2}$-rich magmas are ubiquitously distributed somewhere in the upper mantle beneath the continental crusts. In order to understand the origin and distribution of $\mathrm{CO}_{2}$-rich magmas in the upper mantle beneath the continents, we have measured the compressional wave velocity $(\mathrm{Vp})$ of carbonate melts under high pressure and temperature conditions.

\section{Experimental method}

High pressure and temperature experiments were carried out using a Paris-Edinburgh cell at Beamline $16 \mathrm{BM}-\mathrm{B}, \mathrm{HPCAT}$ of the Advanced Photon Source, USA. A $\mathrm{Si}_{3} \mathrm{~N}_{4}$ buffer rod was used for transmitting

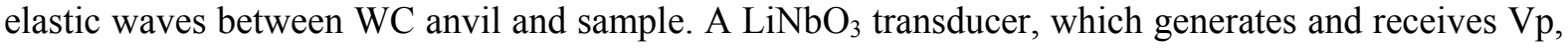
was attached to the top WC anvil. Because melt phase only $25 \mathrm{MHz}$ electrical sine waves were used to determine Vp. The details on ultrasonic measurement setup are described in Kono et al. (2012). The starting materials were prepared by mixing reagent grade carbonate powders in appropriate ratios. The compositions of starting materials thus prepared are $\mathrm{Na}_{2} \mathrm{Mg}\left(\mathrm{CO}_{3}\right)_{2}, \mathrm{Na}_{2} \mathrm{Ca}\left(\mathrm{CO}_{3}\right)_{2}, \mathrm{~K}_{2} \mathrm{Mg}\left(\mathrm{CO}_{3}\right)_{2}$, and $\mathrm{K}_{2} \mathrm{Ca}\left(\mathrm{CO}_{3}\right)_{2}$. The measurements were done up to about $2.2 \mathrm{GPa}$ and $1200^{\circ} \mathrm{C}$.

\section{Experimental results}

The compressible wave velocity in carbonate melts decrease with increasing temperature. The slopes, $\mathrm{dVp} / \mathrm{dT}$, at high pressures obtained in the present study are almost the same as those obtained by the previous study at 1 atmosphere. The $\mathrm{Vp}$ in carbonate melts increases with increasing pressure (Fig. 1).

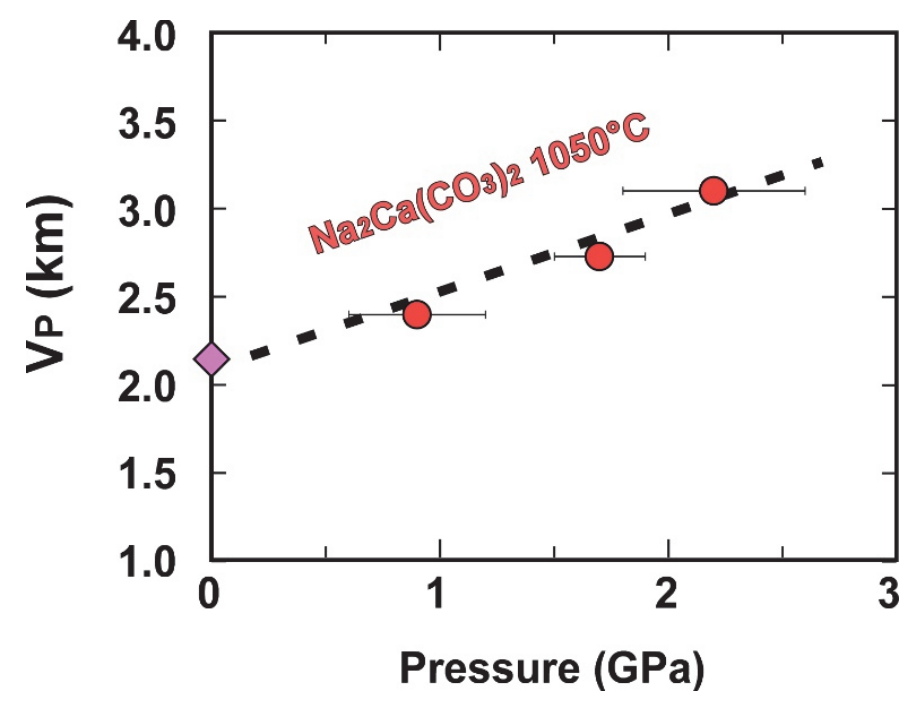

Figure 1: The compressible wave velocity $(\mathrm{Vp})$ in carbonate melt as a function of pressure. 
The $\mathrm{Vp}$ in carbonate melt, $\mathrm{Na}_{2} \mathrm{Ca}\left(\mathrm{CO}_{3}\right)_{2}$, is faster than pure $\mathrm{H}_{2} \mathrm{O}$ and slower than basaltic melt within the pressure and temperature conditions investigated. The $\mathrm{Vp}$ in carbonate melts decrease with increasing mean atomic weight.

\section{Origin of the mid-lithosphere discontinuity in the continents}

It has been reported that seismic body wave velocity drops by 2 to $6 \%$ at the mid-lithospheric depths of about 60 to $150 \mathrm{~km}$ in almost of all the continents (Karato et al., 2015). However, the origin of this reduction in seismic wave velocity has not been understood yet. According to our experimental results, those drops in seismic wave velocity can be explained by the presence of about 1 to 3 vol\% of alkaline carbonate melts in peridotites. The presence of alkaline carbonate melts are often reported as the melt inclusions trapped in mineral grains in mantle xenoliths from sub-continental lithospheric mantle (Guiliani et al., 2012), which is considered to be the direct and natural evidence of the presence of alkaline carbonate melts at the mid-lithospheric depths in continental mantles.

\section{References}

Giuliani A, Kamenetsky V.S., Phillips D, Kendrick M.A., Wyatt B.A, Goemann K (2012) Nature of alkali-carbonate fluids in the sub-continental lithospheric mantle. Geology, 40(11):967-970

Karato S (2015) Mechanisms and geologic significance of the mid-lithosphere discontinuity in the continents. Nature geoscience 8:509-514

Kono Y, Park C, Sakamaki T, Kenny-Benson C, Shen G, Wang Y (2012) Simultaneous structure and elastic wave velocity measurement of $\mathrm{SiO}_{2}$ glass at high pressures and high temperatures in a ParisEdinburgh cell. Rev. Sci. Instrum. 83:033905 